\title{
Working
}

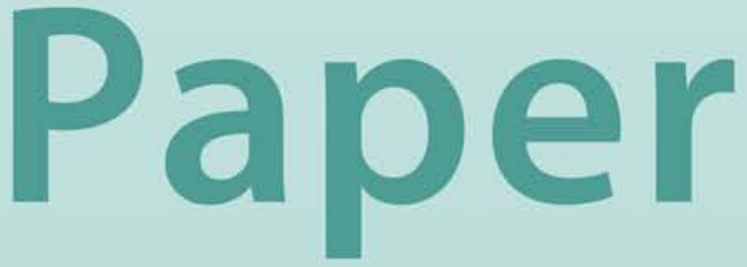


Puttable and Extendible Bonds:

Developing Interest Rate Derivatives for Emerging Markets

Salih N. Neftci and André O. Santos 


\title{
IMF Working Paper
}

\section{IMF Institute \\ Puttable and Extendible Bonds: Developing Interest Rate Derivatives for Emerging Markets}

\author{
Prepared by Salih N. Neftci and André O. Santos ${ }^{1}$ \\ Authorized for distribution by Enzo Croce
}

October 2003

\begin{abstract}
The views expressed in this Working Paper are those of the author(s) and do not necessarily represent those of the IMF or IMF policy. Working Papers describe research in progress by the author(s) and are published to elicit comments and to further debate.
\end{abstract}

This paper analyzes the price stabilizing properties of puttable and extendible bonds, their potential to help develop interest-rate derivative markets, and their use by governments. Their stabilizing properties imply that, when bond prices fall, prices for puttable and extendible bonds fall by less. Their embedded options work as a cushion and replicate the trading gains from hedging long-term bonds with interest rate derivatives. These bonds can help develop interest-rate derivative markets in developing countries and eventually increase demand for long-term government bonds. Informal evidence from OECD countries suggests that these bonds were useful in the 1980 s, when interest rates were volatile.

JEL Classification Numbers: G13, G15

Keywords: Fixed income securities, option pricing theory, financial markets

Authors' E-Mail Addresses: sneftci@wwc.com; asantos2@imf.org

\footnotetext{
${ }^{1}$ The authors are affiliated with the City University of New York and International Monetary Fund, respectively. They would like to thank Carlos Hamilton V. Araujo, Adolfo Barajas, Ralph Chami, Enzo Croce, Connel Fullenkamp, Angela Gaviria, Hugo Juan-Ramon, and Sunil Sharma for insightful comments.
} 
Contents

Page

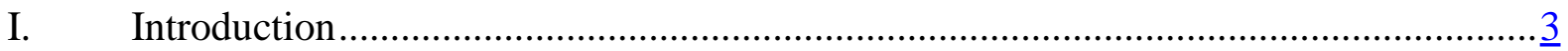

II. The Stabilizing Properties of Puttable and Extendible Bonds ................................. $\underline{5}$

A. Hedging Long Positions in Long-Term Bonds ....................................... 5

B. Puttable and Extendible Bonds Written on Discount and Coupon Bonds......... 7

C. Credit Risk Aspects......................................................................

III. Mimicking Markets for Interest Rate Derivatives on Government Bonds ..................11

A. The Brazilian Government Bond Markets ................................................ 12

B. Some Weaknesses of Emerging Bond Markets ….................................... 15

C. Measuring the Effect of C-Bond Volatility …....................................... $\frac{16}{17}$

D. The Effect of Puttable Bonds ..............................................................

IV. Experience with Puttable and Extendible Bonds ...............................................19

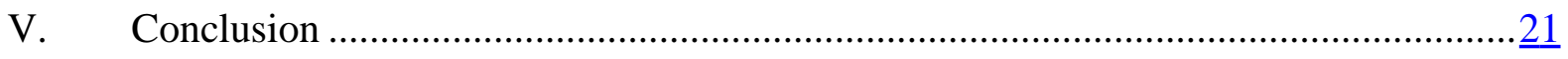

Appendix: Pricing Government Bonds ...............................................................

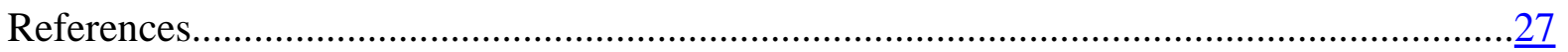

Figures

1. Use of Interest Rate Derivatives by Emerging Markets …..................................... $\underline{6}$

2. Brazil: Composition of Government Securities, June 1994-December 2002 .............13

3. Brazil: Average Maturity of Outstanding Discount Bonds,

July 1996-December 2002 ....................................................................... 13

4. Discount Bond Prices as a Function of Interest Rate Volatility .............................. $\frac{17}{18}$

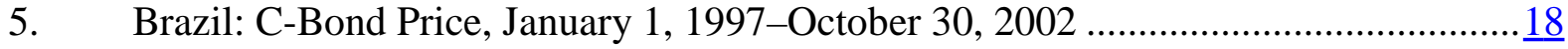

6. Brazil: Puttable Bond Price, January 1, 1997-October 30, 2002 …........................18

Tables

1. Puttable and Extendible Bonds in Selected OECD Countries ...................................19

2. Belgium: Outstanding State Notes, 1996-2001 ................................................

3. Belgium: Descriptive Statistics for Price Changes of 1998 State Note and

1999 Linear Bond, September 14, 2000-October 25, 2002 .............................. 20

4. Sovereign Puttable Bonds and Loans by Emerging Markets, 1997-2001.................. 


\section{INTRODUCTION}

To tap financial markets, borrowers have a broad range of instruments from which to choose. Puttable and extendible bonds are one example. ${ }^{2}$ These bonds give investors the right to sell them back at par to the borrower at a predetermined date or to extend their term beyond a specified date. They are common among private sector issuers in developed countries and in international financial markets, but not among public sector issuers both in developed and emerging markets.

In this paper, we analyze key characteristics of puttable and extendible bonds: the price stabilizing properties of the bonds, the potential of the bonds to start interest rate derivative markets, and the use of the bonds by governments. We argue that such bonds have interesting price stabilizing properties. Merton (1995) shows that puttable bonds are economically equivalent to a portfolio of discount bonds and a risk-free short-term bond. When discount bond prices fall, the put option kicks in and reduces the interest rate risk exposure incurred by investors. By contrast, when discount bond prices increase, the put option has no value and investors increase their risk exposure. Therefore, their price change is limited to a riskfree short-term bond when the put option is in-the-money and tracks a discount bond when the put option is out-of-the-money. We extend Merton's insight by examining other underlying bonds, such as coupon bonds and bonds subject to credit risk. We find that Merton's result remains intact: When prices of coupon bonds or bonds subject to credit risk fall, prices of puttable and extendible bonds written on these bonds fall less.

Due to these price stabilizing properties, we claim that puttable and extendible bonds can take advantage of the convexity gains from volatility in emerging markets. The embedded put and call options work as cushions and replicate the trading gains from convexity when investors hedge their long positions in long-term bonds by short selling short-term bonds and futures contracts. As IOSCO (2002) shows, these interest rate derivative instruments are not available to investors in emerging markets and most investors are hence deprived of benefiting from the convexity gains. Using puttable and extendible bonds would thus be a way to temporarily overcome obstacles in the development of long-term government bond markets.

We suggest that governments can consider using puttable and extendible bonds as part of a debt management strategy that also includes the development of interest rate derivative markets for government bonds. ${ }^{3}$ The informal historical evidence from OECD countries shows that some countries used puttable and extendible bonds in the 1980s when short-term interest rates were high and volatile, the debt-to-GDP ratio was high, and bond futures and

\footnotetext{
${ }^{2}$ Puttable bonds are also known as put bonds or retractable bonds.

${ }^{3}$ See De Broeck, Guillaume, and Van der Stichele (1998) for a discussion of the introduction of futures on government bonds in mature markets.
} 
short selling bonds were not common. Favero and Giavazzi (2002), for example, mention the use of puttable bonds by Italy in the 1980s and also suggest them for lengthening the debt maturity in Brazil.

This does not mean that all government bonds should be puttable. We should caution that traders may be tempted to increase the price volatility of the underlying bond so that they increase the probability of exercising the option embedded in the bond. An analogous example is the stock options given to managers in the 1990s. Managers had an implicit interest in the increase of price volatility so that they could exercise their stock. ${ }^{4}$ In addition, if all bonds were puttable or extendible, the exercise of the put or call option could lead to serious liquidity problems for governments.

Even though some would argue that the fiscal implication of early redemption in the case of puttable or extendible bonds is important, we do not think that it is significantly different from that generated when the government is obliged to buy back its option-free debt before maturity. The Brazilian experience in 2002 is an example of government concern for stability in the secondary markets for bonds and of intervention to buy back debt before its maturity. Therefore, the embedded put and call options make explicit what is already assumed to be an implicit guarantee that the government will buy back its paper. This should help reduce market jitters and avoid overshooting or overreaction of bond markets to price shocks.

We also believe that puttable and extendible bonds can signal to the private sector that the government is committed to macroeconomic stability and fiscal discipline since it is not in the government's interest for the private sector to exercise the embedded option. For example, when the government sells such bonds, it knows that they may be redeemed at sometime in the future when it is least convenient for the government. Governments would then need to make sure that, ex ante, their fiscal position is in order or that they have the fiscal resources to pay for the exercise of the options.

This paper contains four sections. The next section describes dynamic hedging and characterizes puttable and extendible bonds written on discount and coupon bonds with and without credit risk. Section III describes events in Brazil during 1999-2002 that led to a reduction in the share of outstanding discount bonds in the total stock of public debt and simulates puttable bonds written on the Brazilian C-Bond. Section IV looks at the international experience with the public issues of puttable and extendible bonds. The last section concludes with directions for future research.

\footnotetext{
${ }^{4}$ See Tufano (1996) for the argument in the gold mining industry.
} 


\section{The Stabilizing Properties of Puttable and extendible Bonds}

As noted, markets for short selling bonds and futures contracts are not available to investors in emerging markets, and investors are deprived of benefiting from the convexity gains.

How can puttable and extendible bonds replicate the convexity gains when investors hedge their long positions in long-term bonds by short selling short-term bonds and futures contracts? This section answers this question by analyzing dynamic hedging strategies and the stabilizing properties of puttable and extendible bonds. We also incorporate the credit risk aspects of bonds.

\section{A. Hedging Long Positions in Long-Term Bonds}

Let $P_{t}$ dollars be invested in a portfolio consisting of a long-term bond, $B_{t}{ }^{L}$, and a short-term bond, $B_{t}^{S}$ :

$$
P_{t}=\theta_{1} B_{t}^{L}+\theta_{2} B_{t}^{S},
$$

where $B_{t}{ }^{L}$ and $B_{t}{ }^{S}$ are the prices for the long-term and short-term bonds, and $\theta_{1}$ and $\theta_{2}$ are their respective number of units. The value of the portfolio $P_{t}$ changes as time passes because of changes in $B_{t}{ }^{L}$ and $B_{t}{ }^{S}$ :

$$
d P_{t}=\theta_{1} d B_{t}^{L}+\theta_{2} d B_{t}^{S}
$$

We assume that a one-factor interest rate model describes the dynamics of the short-term interest rate. ${ }^{5}$ This assumption implies that there is only one source of randomness in equation (2) since the stochastic differential equations for the short- and long-term bonds have diffusion terms with the same Wiener process. ${ }^{6}$ So we can eliminate all the randomness in equation (2) by selecting the appropriate quantities of each asset in the portfolio. We set them equal to:

$$
\theta_{1}=\frac{\sigma_{S}}{\left(\sigma_{S}-\sigma_{L}\right) B_{t}^{L}} P_{t} \text { and } \theta_{2}=-\frac{\sigma_{L}}{\left(\sigma_{S}-\sigma_{L}\right) B_{t}^{S}} P_{t},
$$

where $\sigma_{L}$ and $\sigma_{S}$ are the diffusion parameters for the long-term and short-term bonds, respectively.

\footnotetext{
${ }^{5}$ See Neftci (2000a) and Rebonato (1998) for a review of one-factor interest rate models. Appendix I shows how the parameters describing the dynamics for discount bonds are a function of the parameters characterizing the dynamics for the short-term interest rate.

${ }^{6}$ See Neftci (2000b) for a justification for a one-factor model to describe the short-term structure of interest rates in emerging markets.
} 
The positions in each asset are then long in the long-term bond and short in the short-term bond. This portfolio is then risk-free and should also yield a return equal to a risk-free investment to avoid arbitrage:

$$
r_{t}\left(\theta_{1} B_{t}^{L}+\theta_{2} B_{t}^{S}\right) d t=\theta_{1} d B_{t}^{L}+\theta_{2} d B_{t}^{S},
$$

where $r_{t}$ is the risk-free short-term interest rate.

Dividing both sides of expression (4) by $\theta_{1}$, we can rewrite it as:

$$
r_{t}\left(B_{t}^{L}+\frac{\theta_{2}}{\theta_{1}} B_{t}^{S}\right) d t=d B_{t}^{L}+\frac{\theta_{2}}{\theta_{1}} d B_{t}^{S} .
$$

In Appendix I we show that the relative quantity ratio $\theta_{2} / \theta_{1}$ can be approximated by the first derivative $B_{y}{ }^{L}$, which measures how much the price for the long-term bond changes as its yield-to-maturity changes by 1 percentage point. This approximation allow us to rewrite expression (5) as:

$$
r_{t}\left(B_{t}^{L}+B_{y}^{L} B_{t}^{S}\right) d t=d B_{t}^{L}+B_{y}^{L} d B_{t}^{S}
$$

where $B_{y}{ }^{L}$ is also known as the hedge ratio.

Note that since there exists a negative and nonlinear relationship between the price of a bond and its yield-to-maturity, the hedge ratio $B_{y}{ }^{L}$ is negative and changes as the yield changes. If the yield increases, the hedge ratio $B_{y}{ }^{L}$ decreases and vice-versa. To keep the long-term bond hedged, we need to rebalance the number of units of the short-term bond in the portfolio as the yield changes. This rebalancing strategy is called a dynamic hedging strategy, requires no net investment, and is self-financing. In addition, the rebalancing strategy allows the investor to get a risk-free return on his portfolio that is generated from the trading gains (or convexity gains).

Figure 1 - Use of Interest Rate Derivatives by Emerging Markets

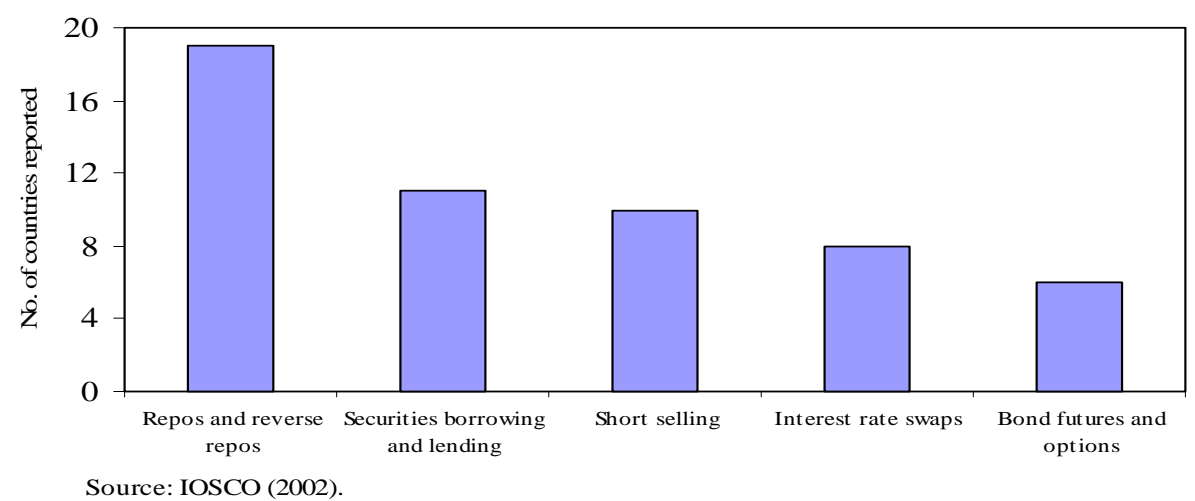


The dynamic hedging strategy above seems a straightforward operation but cannot be easily performed in many emerging markets. It is effective only if we can short sell the short-term bond. As Figure 1, compiled from IOSCO (2002), shows, only 10 out of 22 emerging market countries allow short selling bonds. ${ }^{7}$ Indeed, about the same number of countries allow securities borrowing and lending, which is a precondition for short selling. Therefore, few investors in emerging markets can perform dynamic hedging strategies and extract the convexity gains necessary to cover losses from price fluctuations on their bond holdings.

In addition, where short selling is allowed, investors might not be able to short sell because they are afraid of being caught in a short squeeze, that is, when it is costly to buy the collateral (bonds) to close out the short position. The majority of countries surveyed in IOSCO (2002) have repos and reverse repos, which can help investors acquire the bonds. However, if these instruments are not actively used because of tax treatment or other impediments and if liquidity in the secondary markets for the collateral is low, investors can be cornered. Short selling then becomes impractical and, as a consequence, dynamic hedging strategies based on them are unfeasible.

Investors can make dynamic hedging strategies feasible not only by short selling short-term bonds but also by using bond futures. In this case, investors sell an appropriate number of bond futures written on the underlying long-term bond to hedge one unit of the long-term bond. As the hedge ratio changes through time, the number of futures contracts also needs to be adjusted accordingly so that the portfolio remains delta-neutral or fully hedged. Even though the dynamic hedging strategy using bond futures also seems simple, few emerging markets have bond futures. Therefore, investors cannot benefit from the convexity gains that offset the losses investors incur in their long positions when bond prices fluctuate.

\section{B. Puttable and Extendible Bonds Written on Discount and Coupon Bonds}

Few governments in the developing world are aware that it is possible to mimic markets for short selling bonds and bond futures using puttable and extendible bonds. Merton (1995) suggests that governments can issue puttable and extendible bonds in addition to the usual "vanilla" instruments to mimic open market operations. In this section we use Merton's analysis of the stabilizing properties of puttable bonds written on discount bonds to suggest their use for mimicking markets for short selling short-term instruments.

Puttable bonds are bonds that give their holders the right to sell them back to the government for a fixed strike price, $E$, if the price of the underlying $U$-maturity bond, $B_{t}$, falls below the

${ }^{7}$ The 22 countries in IOSCO (2002) are Argentina, Bangladesh, Brazil, Taiwan Province of China, El Salvador, Hungary, India, Indonesia, Kenya, Korea, Lithuania, Malaysia, Mauritius, Pakistan, Peru, Singapore, Slovenia, South Africa, Thailand, Trindad and Tobago, Tunisia, and Turkey. 
strike price $E$ at time $T$, where $T \leq U$. At time $T$, when the put option expires, puttable bonds have a price equal to:

$$
F_{T}=\operatorname{Max}\left(B_{T}, E\right)
$$

A puttable bond, then, is equivalent to a portfolio of a straight bond and a put option on the underlying bond. Since the right to put back the bond to the government has positive time value, puttable bonds have a higher price and are issued at a lower discount or coupon than a straight bond. One can interpret the price of the put option as what the government charges the private sector for stabilizing financial markets and selling protection that is not widely available.

Similarly, extendible bonds give the holder the right to extend the term of the bond on a fixed date at a predetermined rate. So an extendible bond can be thought of as a short-term bond coupled with a call option to buy a long-term bond at a price $E$ on the predetermined date $T$, while the puttable bond is a long-term bond coupled with a put option to sell the bond at a price $E$ on the predetermined date $T$. In case of European options, due to put-call parity, the valuation of both bonds should be more or less equivalent. ${ }^{8}$ As a consequence, the analysis that follows also applies to extendible bonds.

Since a puttable bond contains a derivative written on the underlying bond, the price $F_{t}$ of a puttable bond depends on time $t$ and the price of the underlying bond $B_{t}$ :

$$
F_{t}=F\left(B_{t}, t\right) \text {. }
$$

The functional form of $F_{t}$ is found by using replicating trading strategies. Let $P_{t}$ dollars be invested in a combination of the puttable bond $F_{t}$ and the underlying discount bond $B_{t}$ :

$$
P_{t}=\theta_{1} F_{t}+\theta_{2} B_{t}
$$

where $\theta_{1}$ and $\theta_{2}$ are units of the puttable bond $F_{t}$ and the underlying bond $B_{t}$, respectively.

The value of the portfolio $P_{t}$ changes as time passes because of changes in $F_{t}$ and $B_{t}$ :

$$
d P_{t}=\theta_{1} d F_{t}+\theta_{2} d B_{t}
$$

We also assume that one-factor interest rate models describe the dynamics of short-term interest rates in developing countries. So we can also eliminate the randomness in equation (10) by selecting the appropriate quantities of each asset in the portfolio, which are equal to:

$$
\theta_{1}=1 \text { and } \theta_{2}=-F_{1} \text {, }
$$

\footnotetext{
${ }^{8}$ See Kalotay and Abreo (1999).
} 
where $F_{1}$ stands for the first derivative of the puttable bond $F_{t}$ with respect to the underlying bond price $B_{t}$ and is also known as the hedge ratio. ${ }^{9}$ As we are short in the underlying bond and long in the puttable bond with the right proportions, random fluctuations cancel out and the portfolio is risk-free. To avoid arbitrage, it should then have a rate of return equal to a risk-free investment:

$$
r_{t} P_{t} d t=d F_{t}-F_{1} d B_{t}
$$

By using equations (9) and (11) in equation (12) and rearranging terms in the resulting equation, we can note that puttable bonds are "economically equivalent" to a portfolio of $F_{1}$ units of the discount bond and $\left(F_{t}-B_{t} F_{1}\right)$ units of the risk-free short-term bond:

$$
d F_{t}=F_{1} d B_{t}+r_{t}\left(F_{t}-F_{1} B_{t}\right) d t .
$$

This economic equivalence results in a particular price dynamics for puttable bonds. Since $0 \leq F_{1} \leq 1$ and $F_{t}$ is twice continuously differentiable, with $F_{11}>0$, as the price $B_{t}$ for the discount bond falls, $F_{1}$ also falls. ${ }^{10}$ This is equivalent to a repurchase of discount bonds by the government, which decreases the interest rate exposure incurred by investors. The reverse is also true. When the price $B_{t}$ for the discount bond increases, $F_{1}$ also increases, which is equivalent to holding more discount bonds. Investors are thus more exposed to interest rate risk. Because of these characteristics, Merton (1995) describes puttable bonds as "the equivalent of a dynamic, 'open market,' trading operation without any need for actual transactions."

What is key to the price dynamics in equation (13) is the automatic cushion mechanism provided by the embedded put option. When discount bond prices fall due to interest rate increases, the value of the put option kicks in and offsets partially the capital loss. The put option then works as a cushion against capital losses. In the extreme case, when the underlying bond price has fallen enough and the put option is in-the-money, a puttable bond behaves like a short-term bond. ${ }^{11}$ On the other hand, when discount bond prices rise, the put option is out-of-the-money and has little effect on puttable bond price changes. In this case, puttable bonds are similar to the underlying discount bonds, with their price changes limited to the price changes of discount bonds.

In equation (13), note that the second term on the right-hand side, $r_{t}\left(F_{t}-F_{1} B_{t}\right) d t$, is similar to the risk-free return obtained from a dynamic hedging strategy with short selling or bond futures. When investors hold a puttable bond, they do not need to buy the underlying

\footnotetext{
${ }^{9}$ See Appendix.

${ }^{10}$ See Hull (2000) and Merton (1990). The Appendix shows that the function $F_{t}$ is found by solving a partial differential equation subject to some boundary conditions.

${ }^{11}$ See Fabozzi (2001).
} 
discount bond and short sell short-term bonds or bond futures to hedge and manage interestrate risk exposures. The puttable bond is able to mimic trading in these markets and replicate the trading gains from convexity (or convexity gains) used to offset losses on the long position in the discount bond. Since few emerging markets allow short selling, securities borrowing and lending, repos, reverse repos, and bond futures, puttable bonds would overcome restrictions in boosting demand for long-term government bonds.

In the case of coupon bonds, the no-arbitrage condition includes an extra term that captures coupon payments both on the underlying coupon and puttable bonds:

$$
r_{t} P_{t} d t=d F_{t}-F_{1} d B_{t}+\left(C_{F}+F_{1} C_{B}\right) d t,
$$

where $C_{B}$ and $C_{F}$ are the coupon payments for the underlying and puttable bonds, respectively. ${ }^{12}$ We can rearrange the extra terms on the right hand-side in equation (15) and the economic interpretation of a puttable bond would remain the same. An investor holding a puttable bond with coupon payments has a net exposure (excluding coupon payments) equivalent to $F_{1}$ units of the underlying coupon bond and $\left(F_{t}-B_{t} F_{1}\right)$ units of the short-term bond:

$$
d F_{t}=F_{1}\left(d B_{t}-C_{B} d t\right)+\left[r_{t}\left(F_{t}-B_{t} F_{1}\right)-C_{F}\right] d t
$$

Since the embedded put option has an implicit value for investors, governments can offer puttable bonds with lower coupons than the ones for underlying coupon bonds. The hybrid nature of a puttable bond with coupons implies that the price of a puttable bond is equal to the price of a coupon bond plus the put option written on the coupon bond. In this sense, puttable bonds are a cheaper source of financing for governments. The government essentially charges investors for the insurance policy provided.

\section{Credit Risk Aspects}

The previous analysis assumed that government bonds are exempt from credit risk. In this section we incorporate the credit risk aspect of government bonds into our analysis.

We assume that swap rates provide a set of default-free interest rates. Hull, Predescu, and White (2002) argue that even though U.S. treasury bonds do not have credit risk, other factors such as liquidity, taxation, and regulation affect them. They thus favor the use of swap rates as risk-free interest rates. We can extend their argument to emerging markets,

12 See Merton (1990). The Appendix shows that dynamics for discount and coupon bonds are slightly different. The latter includes the coupon rate in the drift component. The pricing formula for the puttable bond written on the coupon bond would also contain the coupon payment rate. 
where a swap could be even less risky than a treasury bond because the counterparty is a highly rated financial institution.

Assuming different credit risk for different financial instruments, we extend the previous analysis to a puttable bond written on a risky bond. As in Duffie and Singleton (1999), we replace the default-free short-term interest rate in the pricing formula for our puttable bonds by an interest rate adjusted for the default risk:

$$
B_{t}=E_{t}^{Q}\left(\exp \left(-\int_{s=t}^{T}\left(r_{s}+h_{s} L_{s}\right) d s\right) \operatorname{Max}\left(B_{T}, E\right)\right),
$$

where $E_{t}^{Q}$ is the expectation operator under the risk-neutral probabilities; $h_{t}$ is the exogenous intensity or hazard rate process; and $L_{t}$ is the exogenous loss process given by $L_{t}=1-R_{t}$, where $R_{t}$ is the recovery process. ${ }^{13}$ Equation (16) states that the price of a puttable bond is the present value of the put option payoff at time $T$, discounted at the default-adjusted rate $\left(r_{t}+h_{t} L_{t}\right)$ instead of the short-term interest rate $r_{t}$. If both the puttable and underlying bonds do not pay coupon and if the puttable bond at time $t$ is a function of the underlying bond at time $t, F_{t}=F\left(B_{t}, t\right)$, then the no-arbitrage condition implies that:

$$
d F_{t}=F_{1} d B_{t}+\left(r_{t}+h_{t} L_{t}\right)\left(F_{t}-F_{1} B_{t}\right) d t .
$$

As before, puttable bonds are equivalent to a portfolio of $F_{1}$ units of the underlying bond and $\left(F_{t}-F_{1} B_{t}\right)$ units of a short-term bond adjusted by a premium for the credit risk incurred by bondholders. Price changes for puttable bonds would still be limited to the price changes for the underlying bond-which includes credit risk in its dynamics-when prices for the underlying bond go up, and would be limited to a default-adjusted short-term interest rate when prices for the underlying bond go down. With credit risk, puttable bonds would still be able to mimic markets for short selling short-term bonds and bond futures.

\section{MIMICKING MARKETS FOR INTEREST RATE DERIVATIVES ON GOVERNMENT BONDS}

In this section, we highlight events in Brazil that affected the government debt composition during 1999-2002. Our objective is to show what happens when markets for futures contracts and short selling bonds are missing. We then simulate a puttable bond written on Brazilian CBonds from January 1, 1997, to October 30, 2002 to show how price changes for puttable bonds would be less than price changes for $\mathrm{C}$-Bonds and to mimic the convexity gains that

${ }^{13}$ See the Appendix for the stochastic and partial differential equations for the discount bond. 
mutual funds would have extracted if interest rate derivative markets had been used in 2002. ${ }^{14}$

\section{A. The Brazilian Government Bond Markets}

In November 1999 the Brazilian government embarked on a program to lengthen the term and duration of its debt securities and to reduce its financing costs. ${ }^{15}$ The program included more than twenty measures to be implemented gradually. The measures were intended to allow better debt and cash management by the treasury, to introduce new market transactions with government securities, to improve secondary market liquidity, and to increase central bank consultations with the private sector.

In addition to the measures announced in 1999, the treasury also set objectives for debt management in $2000 .{ }^{16}$ The treasury sought to minimize costs over the long run while limiting market and liquidity risks. It pursued this objective by lengthening the debt maturity in public auctions, gradually substituting indexed debt by discount bonds, developing a term structure of interest rates, and standardizing debt instruments. As a result of the partial implementation of the measures, the adoption of debt management objectives and strategies, and the decreasing interest rates after the 1999 Brazilian crisis, the average maturity and share of outstanding discount bonds in the total stock of public debt improved in 2000 as can be seen in Figures 2 and 3. ${ }^{17}$

${ }^{14} \mathrm{C}$-Bonds are the most traded and liquid Brazilian Brady bonds in international financial markets.

${ }^{15}$ See Central Bank of Brazil (2002d).

${ }^{16}$ See National Treasury of Brazil (2001) and International Bank for Reconstruction and Development and International Monetary Fund (2001) for details on the design of debt management objectives and strategies.

${ }^{17}$ See Central Bank of Brazil (2001). In the first quarter of 2000 the Brazilian treasury was able to sell six-month and 1-year discount bonds in public auctions. 
Figure 2. Brazil: Composition of Government Securities,

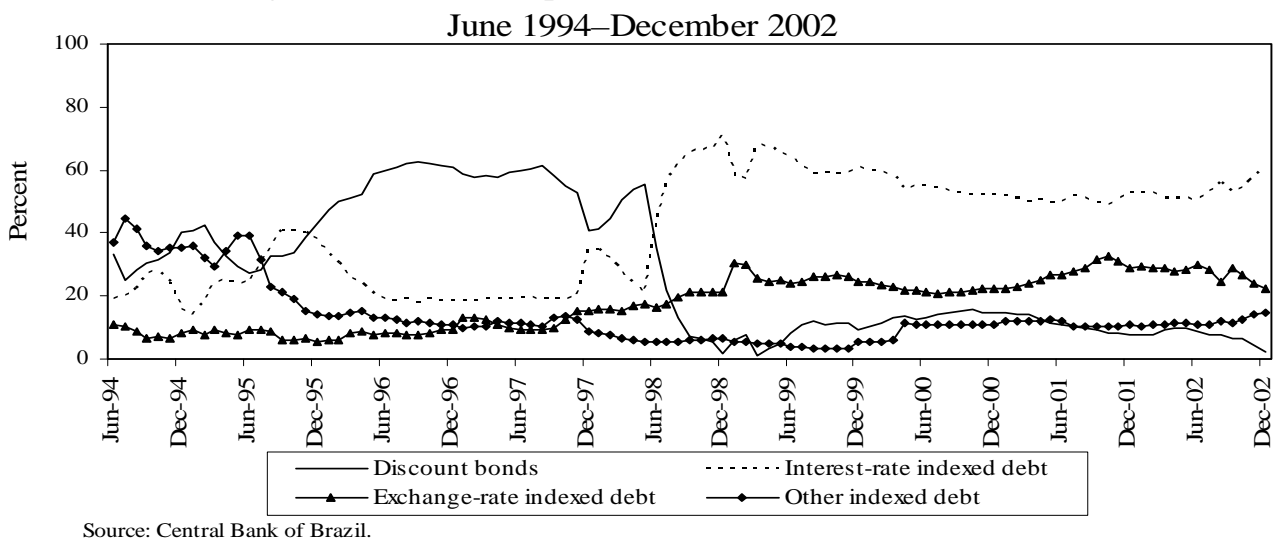

However, the debt management improvements in 2000 were negatively affected by the Argentine crisis and the U.S. recession in 2001. With an increase in interest rates, the Brazilian treasury faced a dilemma in 2001: Whether to issue discount bonds with shorter maturities $\backslash$ or to increase the share of indexed debt with longer maturities. ${ }^{18}$ Given the high liquidity risk at the time, the treasury mainly relied on reducing the share of discount bonds in the total stock of public debt. ${ }^{19}$

Figure 3. Brazil: Average Maturity of Outstanding Discount Bonds, July 1996-December 2002

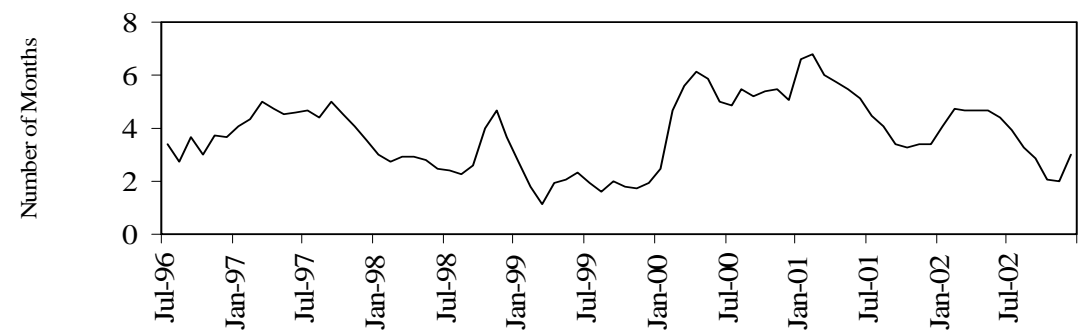

Sources: Central Bank of Brazil and National Treasury of Brazil.

After a calm first quarter, Brazilian financial markets suffered more turmoil in 2002. The uncertainty surrounding the presidential elections, the difficulties in financing the balance of payments during the year, and the implementation of mark-to-market accounting rules for mutual funds in May 2002 led to high levels of discounts on the indexed debt and an increased volatility in discount bond prices. ${ }^{20}$ Investors reacted to this volatility in

${ }^{18}$ See National Treasury of Brazil (2002).

${ }^{19}$ See Central Bank of Brazil (2002a).

${ }^{20}$ See Central Bank of Brazil (2002d). 
government bond markets and the drop in earnings in mutual funds by fleeing from mutual funds-from May 2002 to August 2002, around R\$ 55 billion was withdrawn. ${ }^{21}$

Authorities in Brazil responded to the run on mutual funds by shortening the debt maturity and loosening the fair-value accounting rules. In particular, the debt management strategy for discount bonds was to issue shorter maturities. ${ }^{22}$ Given the high uncertainty in Brazilian financial markets, authorities also decided to exempt from the fair-value accounting rule assets with maturity of less than one year, making all other treasury securities unattractive. ${ }^{23}$

Even though the measures introduced in November 1999 acknowledged the important role of derivative instruments in increasing liquidity in secondary markets for government securities, the use of derivatives by the private sector did not occur. In December 1999, the central bank consolidated all laws concerning forward, repos (and reverse repos), and options on fixed income securities. ${ }^{24}$ This consolidation was expected to create flexible trading conditions in government bond markets. However, except for repos (and reverse repos), IOSCO (2002) still listed Brazil as a country that did not allow short selling, securities borrowing and lending, bond futures and options, and interest rate swaps to enhance liquidity in government bond markets. ${ }^{25}$

Indeed, in the middle of the run on mutual funds in 2002, authorities in Brazil raised the possibility that the central bank would sell put options on bonds. ${ }^{26}$ Authorities felt a need to introduce a derivative instrument to hedge the interest rate risk exposure by investors in government bonds. Puttable and extendible bonds contain embedded options that work as a cushion and offset losses due to the fall in bond prices. They would then help protect investors from the interest rate risk.

${ }^{21}$ Figures are from the National Treasury of Brazil.

${ }^{22}$ See Central Bank of Brazil (2002d).

${ }^{23}$ See Securities and Exchange Commission of Brazil (2002).

${ }^{24}$ See Central Bank of Brazil (1999).

${ }^{25}$ One-day bond forward contracts are negotiated in the electronic system SIBEX run by the Rio de Janeiro Stock Exchange (BVRJ). Hybrid short-term interest-rate futures contracts are traded in the Brazilian Mercantile \& Futures Exchange (BMF). The object of the futures contracts is the average interbank market interest rate. So futures contracts are an imperfect hedge for government bonds.

${ }^{26}$ See Central Bank of Brazil (2002b) and (2002e). 


\section{B. Some Weaknesses of Emerging Bond Markets}

Consider a sovereign default-free discount bond with maturity $U$. Let its time $t$ arbitrage-free price be denoted by $B\left(r_{t}, t ; U\right)$. It can be shown that the price of this discount bond, without any embedded option, will satisfy the partial differential equation: ${ }^{27}$

$$
B_{2}-r_{t} B_{t}+\left(a\left(r_{t}, t\right)-b\left(r_{t}, t\right) \lambda_{t}\right) B_{1}+\frac{1}{2} b(r, t)^{2} B_{11}=0
$$

with the boundary condition:

$$
B\left(r_{U}, U ; U\right)=1 \text {. }
$$

Here the $a\left(r_{t}, t\right)$ and $b\left(r_{t}, t\right)$ are the drift and diffusion parameters in the stochastic differential equation for the short-term interest rate $r_{t}$, and $\lambda$ is the market price of risk:

$$
\frac{\left(\alpha-r_{t}\right)}{\sigma}=\lambda_{t},
$$

where $\alpha$ and $\sigma$ are the drift and diffusion parameters in the stochastic differential equation for the bond price.

This equation shows an important source of income for sovereign bond traders if $B_{11}$ and/or $b\left(r_{t}, t\right)$ is large enough. In fact, in the above partial differential equation the first three terms can be regarded as the "daily" net cost of holding the bond position, apart from convexity gains. The last term can be interpreted as daily gains from convexity. These latter gains are due to volatility in the underlying short-term interest rate $r_{t}$.

What is important for us is that these daily gains have two components. One is the result of the earnings from passing time, and the other is due to volatility in the $r_{t}$. These latter gains are known as convexity or Gamma gains and play a significant role in markets for highly rated sovereign bonds.

Convexity gains basically suggest the following. If the bond's second derivative with respect to $r_{t}$ and the interest rate volatility is high enough, then oscillations in the short rate will lead to significant trading gains for the long position holder. It may seem paradoxical, but a sudden increase in volatility may lead to an increase in the price of the long bond. In fact, this statement should be qualified. Everything else being the same, an increase in interest rate volatility will increase the bond price. The critical statement here is, ceteris paribus, because this means credit risk remains the same. There is no doubt that if the credit risk of a bond were to increase, the bond value would go down. It is possible that increased interest rate volatility increases credit risk and hence has a negative effect on the bond price. Thus, in the

${ }^{27}$ See the Appendix. 
discussion below we omit such effects in order to emphasize the effect of convexity on the bond price.

\section{Measuring the Effect of C-Bond Volatility}

An example of convexity gains is shown for Brazil using the daily returns of the Brazilian C-bond from January 1, 1997, to October 30, 2002. ${ }^{28}$ We use the Vasicek model for the short-term interest rate and calculate the closed form formula for a discount bond having the same yield structure. The Vasicek model gives the price of a default-free pure discount bond as:

$$
\begin{gathered}
C(t, U)=\frac{(1-\exp (-a(U-t)))}{a} \\
A(t, U)=\exp \left(\frac{(C(t, U)-U)\left(a^{2} d-1 / 2 b^{2}\right)}{a^{2}}-\frac{b^{2} C(t, U)^{2}}{4 a}\right) \\
B(t, U)=A(t, U) \exp \left(-C(t, U) r_{t}\right)
\end{gathered}
$$

where $a, d$, and $b$ are the parameters of the mean reverting dynamics assumed for the shortterm rate $r_{t}$ :

$$
d r_{t}=a\left(d-r_{t}\right) d t+b r_{t} d W_{t}
$$

For the Brazilian C-bond we used the values:

$$
b=0.50, a=0.90, d=0.11,
$$

and evaluated the discount curve $B\left(r_{t}, t ; U\right)$ at the mean interest rate 11 percent. We used two levels of volatilities. In one case (absolute) volatility was taken as 5 percent a year, and in the other, volatility was taken as 15 percent. The two discount curves are shown in Figure 4 . We see that increased volatility leads to much higher long bond prices. In fact, the price of a 30 -year bond would be about 30 percent higher in a more volatile environment. The price of a 10 -year bond would increase by about 10 percent.

The critical point is this: in an environment where high volatility does not lead to credit risk changes, an increase in interest rate volatility would increase bond prices and is not detrimental to portfolios that are marked to market. But for this be true, there must be liquid tools and markets that bond traders can use to extract the Gamma gains expressed by the component $1 / 2 B_{11} b(r, t)^{2}$ in the partial differential equation shown above. This is done by taking positions in liquid interest rate futures or in short-term bonds. These positions are in

${ }^{28}$ We use the Brazilian C-Bond for liquidity reasons and data availability. 
the opposite direction to the position in the long bond. For example, a long bond holder will short sell $B_{1}$ units of the futures contract. Adjustments in this "delta-hedge" would extract the Gamma gains.

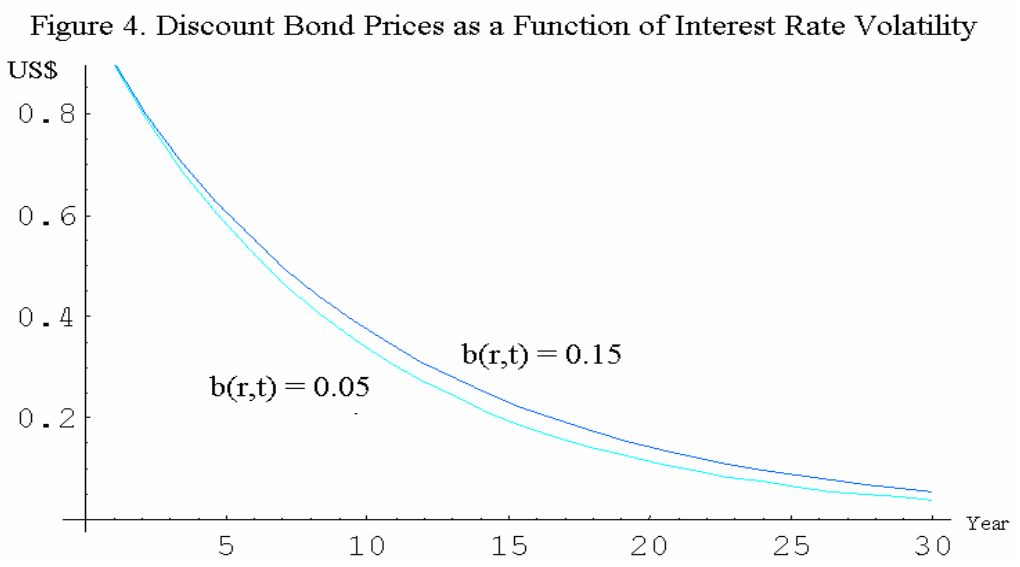

In emerging markets there are two major hurdles for extracting convexity gains. First, there are no markets for liquid interest rate derivatives. Second, interest rate volatility leads to significant increases in credit risk and lowers the bond's price. This implies that traders in emerging markets cannot benefit from the positive effects of volatility increases, yet suffer from the negative ones. Thus, changes in volatility have significantly different effects on the bond portfolios. A newly introduced mark-to-market requirement would lead a bond portfolio manager to lower his exposure to long-term interest rate movements. This increases bond market volatility and at the same time causes shortening of the maturities on new issues.

\section{The Effect of Puttable Bonds}

One advantage of puttable bonds is that the embedded option will increase in value when volatility increases. This increase in option's value would play the role of "Gamma trading" that is available to traders in mature markets and would balance out the negative effect of increased volatility on credit risk. Hence, puttable options can be used to introduce tradable convexity gains in emerging markets. 
Figure 5. Brazil: C-Bond Price, January 1, 1997 - October 30, 2002

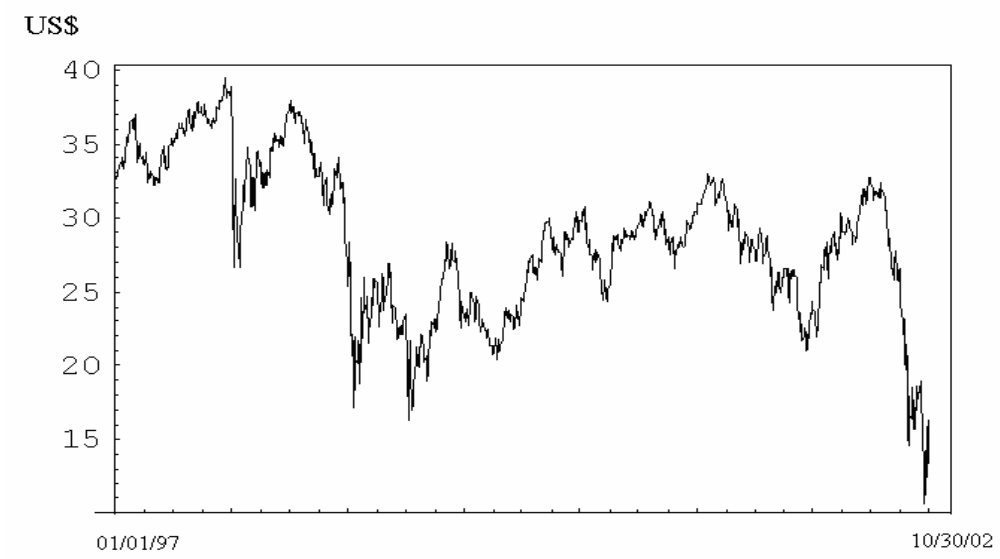

To see the effect of puttable bonds on Brazilian bond portfolios, we use daily returns data on the Brazilian C-Bond to calculate the price volatility of a 10-year discount bond with the same yield as the $\mathrm{C}$-Bond. Figure 5 shows the explosive price volatility during the recent election and after the mark-to-market requirement in 2002, when the bond decreased by about 50 percent.

Figure 6. Brazil: Puttable Bond Price, January 1997 - October 30, 2002

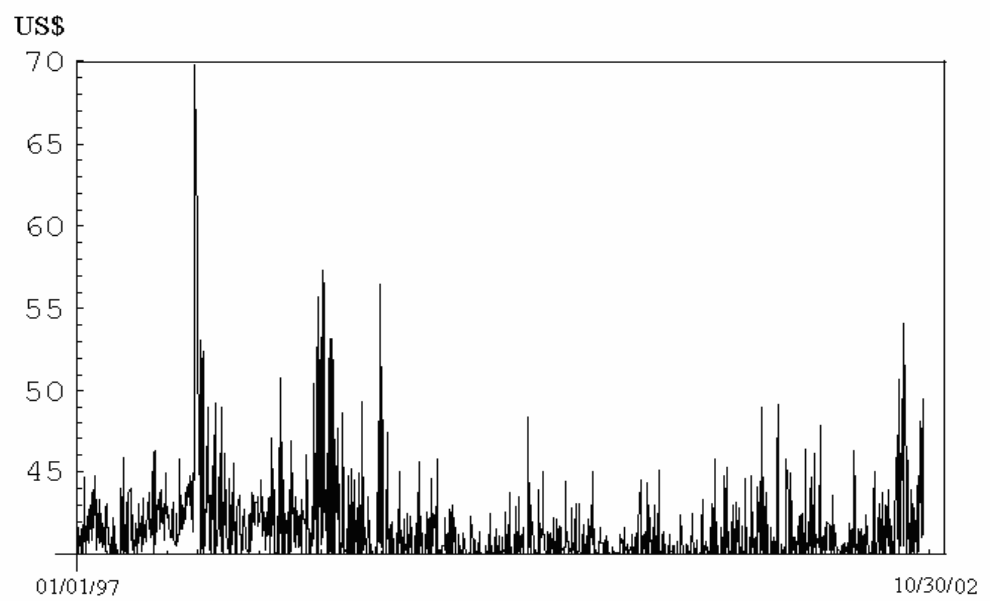

Using the Black-Scholes formula we then calculate an approximate value for the same bond that contains a 1-year put option with the strike price set at 40. Figure 6 shows how the addition of a put option in this fictitious bond would have stabilized bond portfolios in Brazil and, in fact, would have led to higher overall bond values in Brazil in the latest period. ${ }^{29}$

${ }^{29}$ Of course a more detailed study would model the bond dynamics jointly with sovereign credit dynamics for Brazil and then simulate the effects of adding put options. But this 


\section{EXPerience With PutTable AND EXTENDible BondS}

What is the historical evidence on the use of puttable and extendible bonds by governments? Governments in OECD countries have used such bonds as a way to reduce their financing costs. Table 1 reports puttable and extendible bonds issued by Austria, Belgium, Canada, France, Germany, Italy, the Netherlands, the United Kingdom, and the United States. Note that, except for Belgium, most countries issued puttable and extendible bonds in the 1980s, when interest rates were high and volatile. Countries with high debt levels such as Belgium and Italy have used puttable and extendible bonds as well.

Table 1. Puttable and Extendible Bonds in Selected OECD Countries

\begin{tabular}{|c|c|c|c|}
\hline Country & Type & Characteristics & Issue \\
\hline Austria & Puttable 1/ & Floating-rate notes & Currently in use \\
\hline \multirow[t]{2}{*}{ Belgium } & Puttable & Floating-rate notes & Issued until 1991. New issues after 1994 \\
\hline & Extendible & $\begin{array}{l}\text { State coupon bonds (Bons d'État); } 5 \\
\text { years extendible to } 7 \text { years }\end{array}$ & Currently in use \\
\hline Canada & Extendible & Medium-term coupon bonds & $\begin{array}{l}\text { Issued during 1967-82, and traded } \\
\text { between 1967-87 }\end{array}$ \\
\hline France & Extendible & $\begin{array}{l}\text { Coupon bonds (Emprunts à Fenêtre et } \\
\text { Prorogeables) }\end{array}$ & Issued during 1983-86 \\
\hline Germany & Puttable & $\begin{array}{l}\text { Loans against borrowers' notes } \\
\text { (Schuldscheine), typically } 3 \text { to } 10 \\
\text { years }\end{array}$ & Currently being redeemed \\
\hline Italy & Extendible & $\begin{array}{l}\text { Treasury certificates with option } \\
(C T O) \text {, fixed coupon; } 3 \text { - and } 4 \text {-year } \\
\text { securities extendible with } 3 \text { and } 4 \\
\text { years more, respectively }\end{array}$ & Issued during 1988-92 \\
\hline Netherlands & Extendible & Coupon bonds & Issued until 1984 \\
\hline $\begin{array}{l}\text { United } \\
\text { Kindgom }\end{array}$ & Extendible & $\begin{array}{l}\text { Coupon bonds and inflation-indexed } \\
\text { bonds }\end{array}$ & $\begin{array}{l}\text { From early } 1980 \text { s, with last redemption } \\
\text { in } 1999\end{array}$ \\
\hline United States & Puttable & Three coupon bond issues in 1933 & Last issue redeemed in 1962 \\
\hline
\end{tabular}

Belgium, in particular, is an interesting case. The Belgian treasury issues state notes, which are long-term securities with fixed coupons. Only private individuals, nonprofit organizations, and public institutions have access to its primary market. Currently, there is one outstanding note that is extendible: the 5-year state note, which gives the right to the debt holder of extending the maturity for two extra years (to 7 years). Table 2 shows the evolution of state notes during 1996-2001. State notes rose from 0.64 percent and 0.50 percent of the long-term and total domestic government debt, respectively, in 1996 to 3.31 percent and 2.85 percent in 2001.

would, by itself, be a major calibration effort. Our purpose here is to look simply at an example and get some rough idea about the impact of puttable bonds. 
Table 2. Belgium: Outstanding State Notes, 1996-2001

\begin{tabular}{cccc}
\hline & \multicolumn{3}{c}{ State Notes } \\
\cline { 2 - 4 } & In millions of Euros & \% of long-term bonds & \% of domestic bonds \\
\hline 1996 & 1,106 & 0.64 & 0.50 \\
1997 & 2,286 & 1.30 & 1.02 \\
1998 & 3,880 & 2.12 & 1.73 \\
1999 & 4,913 & 2.46 & 2.08 \\
2000 & 6,119 & 2.93 & 2.52 \\
2001 & 7,122 & 3.31 & 2.85 \\
\hline
\end{tabular}

Source: National Bank of Belgium.

If we compare price movements for Belgian linear bonds (the underlying asset) and state notes (the extendible bond), we would expect Belgian state notes to move less than Belgian linear bonds when prices fall. Equation (15) above shows that an investor holding a state note with coupon payments has a net exposure (excluding coupon payments) of $F_{1}$ units of the underlying linear bond and $\left(F_{t}-B_{t} F_{1}\right)$ units of the short-term bond. Since $0 \leq F_{1} \leq 1$ and $F_{t}$ is twice continuously differentiable, with $F_{11}>0$, as the price of the linear bond falls, $F_{1}$ also falls. This is equivalent to a repurchase of linear bonds by the government, which decreases the interest rate exposure incurred by investors. Table 3 shows some basic statistics for the price changes (from September 14, 2000, to October 25, 2002) of the 4.2 percent state note, issued in 1998, due September 4, 2003 and the 4 3/4 percent linear bond, issued in 1999, due September 28, 2005. The evidence suggests that price changes for the 4.2 percent state note were less than those for the $43 / 4$ percent linear bond.

Table 3. Belgium: Descriptive Statistics for Price Changes of the 1998 State Note and the 1999 Linear Bond, September 14, 2000-October 25, 2002

\begin{tabular}{lcc}
\hline & $\begin{array}{c}\text { 1998 State } \\
\text { Note } 1 /\end{array}$ & $\begin{array}{c}\text { 1999 Linear } \\
\text { Bond 2/ }\end{array}$ \\
\hline Mean & 0.01 & 0.01 \\
Median & 0.00 & 0.01 \\
Maximum & 0.43 & 1.71 \\
Minimum & -0.36 & -1.72 \\
Std. Dev. & 0.10 & 0.20 \\
Skewness & -0.03 & -0.19 \\
Kurtosis & 2.38 & 18.80 \\
Observations & 552 & 552 \\
\hline Soure: Datastrean
\end{tabular}

Source: Datastream.

1/ 4.2\% State Note, due September 4, 2005.

2/ 4 3/4 linear bond, due September 14, 2005.

Emerging markets have also tapped international markets with puttable bonds. Table 4 shows that even though there was a decline in the issuance of puttable bonds by developing countries during 1997-2001, these bonds still remained an important source of financing for 
developing countries. Therefore, puttable bonds have also been used by emerging markets to smooth price changes of their international debt.

Table 4. Sovereign Putable Bonds and Loans by Emerging Markets,

1997-2001

\begin{tabular}{lrrrrr}
\hline \multicolumn{7}{c}{ (In millions of U.S. dollars) } \\
\hline Putable & 1997 & 1998 & 1999 & 2000 & 2001 \\
Of which are loans & 3,052 & 4,064 & 2,543 & 1,295 & 2,062 \\
Number of transactions & 555 & 358 & 94 & 265 & 0 \\
\hline Source: IMF (2002). & 22 & 12 & 12 & 7 & 3 \\
\hline
\end{tabular}

\section{Conclusion}

This paper analyzes the stabilizing role that puttable and extendible bonds can play in government securities markets. It finds that these bonds are less price sensitive than underlying bonds are to increases in short-term interest rates. When the prices of the underlying bonds fall, puttable and extendible bond prices fall less than those of the underlying bonds.

In addition to their stabilizing properties, puttable and extendible bonds can also mimic markets for short selling short-term bonds and futures. These derivatives instruments are important to investors since they allow them to extract the convexity gains that offset losses in long positions in long-term bonds. However, the derivatives markets that support the hedging of long-term bonds are absent in many emerging markets. Where absent, governments can therefore issue puttable or extendible bonds to help boost the demand for their long-term government bonds.

It appears to us that governments could issue puttable or extendible bonds as a transitory financing source until liquid and transparent interest rate derivative markets are established and as a debt strategy to move from indexed bonds to fixed-interest coupon bonds. Due to their lower price-sensitivity to short-term interest rate changes, puttable and extendible bonds can be an alternative to the issuing of indexed debt in periods of market turbulence. Indeed, historical evidence in OECD countries shows that many countries did use such bonds during the 1980s, when interest rates were high and volatile and countries did not have well established interest rate derivative markets. 


\section{Pricing GovernMent BONDS}

\section{Discount bonds and hedging}

We assume that bond prices with maturity at time $U$ are a function of the short-term risk-free interest rate $r_{t}$ and time $t$ :

$$
B_{t}=B\left(r_{t}, t ; U\right)
$$

The dynamics for the short-term $r_{t}$ is given by the stochastic differential equation:

$$
d r_{t}=a\left(r_{t}, t\right) d t+b\left(r_{t}, t\right) d W_{t},
$$

where the drift $a\left(r_{t}, t\right)$ and the diffusion $b\left(r_{t}, t\right)$ parameters are assumed to be known, and $W_{t}$ is the standard Brownian motion. We also assume that the instantaneous variance, $b\left(r_{t}, t\right)^{2}$, is nonstochastic or a function of time.

In this paper, we rely heavily on the assumption that one-factor interest rate models describe movements in the term structure of interest rates in developing countries. This assumption implies that any change in short-term interest rates is followed by a parallel shift in the whole yield curve. This might indeed be a reasonable approximation in emerging markets, where the term structure is short. For pricing puttable or extendible bonds, one-factor interest rate models can be good approximations.

Applying Ito's Lemma to $B\left(r_{t}, t ; U\right)$ and using equation (25) yields:

$$
d B_{t}=\left[B_{1} a\left(r_{t}, t\right)+B_{2}+\frac{1}{2} B_{11} b\left(r_{t}, t\right)^{2}\right] d t+B_{1} b\left(r_{t}, t\right) d W_{t},
$$

where $B_{i}$ and $B_{i i}$ indicate the first and second derivatives with respect to the ith argument, respectively. We can rewrite this stochastic differential equation for bonds, of all maturities, as:

$$
d B_{t}=\alpha B_{t} d t+\sigma B_{t} d W_{t},
$$

where the drift component, $\alpha B_{t}$, equals:

$$
\alpha B_{t}=B_{1} a\left(r_{t}, t\right)+B_{2}+\frac{1}{2} B_{11} b(r, t)^{2}
$$

and the diffusion component, $\sigma B_{t}$, is:

$$
\sigma B_{t}=B_{1} b\left(r_{t}, t\right)
$$


Merton (1990) shows that bonds of different maturities offer the same risk premia adjusted by the corresponding volatility. So we can define the market price of interest rate risk, $\lambda\left(r_{t}, t\right)$, as:

$$
\frac{\left(\alpha-r_{t}\right)}{\sigma}=\lambda_{t}
$$

and use it in expressions (28) and (29) to obtain a partial differential equation, which we solve for the bond price, $B_{t}$, as a function of the short-term interest rate, $r_{t}$. Note that expressions (28) and (29) contain an unknown drift $\alpha B_{t}$. To replace $\alpha B_{t}$ in the equations, we first rewrite the market price of risk as:

$$
\frac{B_{t}\left(\alpha-r_{t}\right)}{b\left(r_{t}, t\right) B_{1}}=\lambda_{t}
$$

which gives:

$$
\alpha B_{t}=r_{t} B_{t}+b\left(r_{t}, t\right) B_{1} \lambda_{t} .
$$

Then we substitute $\alpha B_{t}$ in expression (28) by the right-hand side of (31) and rearrange the resulting equation as:

$$
B_{2}-r_{t} B_{t}+\left(a\left(r_{t}, t\right)-b\left(r_{t}, t\right) \lambda_{t}\right) B_{1}+\frac{1}{2} b(r, t)^{2} B_{11}=0
$$

This is a partial differential equation that can be solved for $B_{t}$ subject to the boundary condition:

$$
B\left(r_{U}, U ; U\right)=1 \text {. }
$$

To obtain the hedging strategy, let $P_{t}$ dollars be invested in a portfolio of long-term bonds, $B_{t}^{L}$, and short-term bonds, $B_{t}^{S}$ :

$$
P_{t}=\theta_{1} B_{t}^{L}+\theta_{2} B_{t}^{S}
$$

where $\theta_{1}$ and $\theta_{2}$ are units of the long-term and short-term bonds, respectively. As time passes, the value of the portfolio $P_{t}$ changes according to:

$$
d P_{t}=\theta_{1} d B_{t}^{L}+\theta_{2} d B_{t}^{S}
$$

where we describe the dynamics for each bond by a similar stochastic differential equation as in (27).

Since we assume that the short-term interest rate is the only source of randomness in equation (2'), we can eliminate the randomness by selecting the appropriate quantities of each asset in the portfolio. We set them equal to:

$$
\theta_{1}=\frac{\sigma_{S}}{\left(\sigma_{S}-\sigma_{L}\right) B_{t}^{L}} P_{t} \text { and } \theta_{2}=-\frac{\sigma_{L}}{\left(\sigma_{S}-\sigma_{L}\right) B_{t}^{S}} P_{t} \text {. }
$$


These positions in the two bonds are equivalent to being long in the long-term bond and short in the short-term bond. The portfolio is then risk-free and should also yield a return equal to a risk-free investment to avoid arbitrage:

$$
r_{t}\left(\theta_{1} B_{t}^{L}+\theta_{2} B_{t}^{S}\right) d t=\theta_{1} d B_{t}^{L}+\theta_{2} d B_{t}^{S}
$$

Dividing both sides of (4') by $\theta_{1}$, we can rewrite it as:

$$
r_{t}\left(B_{t}^{L}+\frac{\theta_{2}}{\theta_{1}} B_{t}^{S}\right) d t=d B_{t}^{L}+\frac{\theta_{2}}{\theta_{1}} d B_{t}^{S}
$$

We can use ( $\left.3^{\prime}\right)$ for $\theta_{1}$ and $\theta_{2}$ to write the ratio $\theta_{2} / \theta_{1}$ as:

$$
\frac{\theta_{2}}{\theta_{1}}=-\frac{\sigma_{L} B_{t}^{L}}{\sigma_{S} B_{t}^{S}},
$$

which is equivalent to:

$$
\frac{\theta_{2}}{\theta_{1}}=-\frac{B_{1}^{L}}{B_{1}^{S}},
$$

where $B_{1}{ }^{L}$ and $B_{1}{ }^{S}$ stand for the first derivative of the long-term and short-term bond prices with respect to the short-term risk-free interest rate, respectively. If $B_{t}{ }^{S}$ is the bond with the shortest maturity available in the market, we assume that $B_{1}{ }^{S}=-1$. In this case, any change in the short-term interest rate is fully compensated by a negative price change for the short-term bond; that is, $\delta B_{t}^{S}=-\delta r_{t}$.

As mentioned above, one-factor interest rate models imply that any change in the short-term interest rate that affects the short end of the term structure also affects the long end in the same way. We can then approximate the changes in the short-term interest rate, $\delta r_{t}$, by the changes in the yield-to-maturity of the long-term bond, $\delta y_{t}{ }^{L}$, and $B_{1}{ }^{L}$ by the first derivative $B_{y}{ }^{L}$. This allows us to rewrite (33) as:

$$
\frac{\theta_{2}}{\theta_{1}}=B_{y}^{L}
$$

and ( $\left.5^{\prime}\right)$ as:

$$
r_{t}\left(B_{t}^{L}+B_{y}^{L} B_{t}^{S}\right) d t=d B_{t}^{L}+B_{y}^{L} d B_{t}^{S}
$$

where $B_{y}{ }^{L}$ is also known as the hedge ratio. 


\section{Puttable discount bonds}

In the case of puttable bonds, their price depends only on the value of the underlying bond $B_{t}$ :

$$
F_{t}=F\left(B_{t}, t\right) \text {. }
$$

Using Ito's Lemma, we can find the stochastic differential equation for the puttable bond to equal:

$$
d F_{t}=\left[F_{1} \alpha B_{t}+F_{2}+\frac{1}{2} F_{11} \sigma^{2} B_{t}^{2}\right] d t+F_{1} \sigma B_{t} d W_{t}
$$

Recall that the portfolio $P_{t}$ is invested in a combination of $\theta_{1}$ units of the puttable bond and $\theta_{2}$ units of the underlying discount bond $B_{t}$ :

$$
P_{t}=\theta_{1} F_{t}+\theta_{2} B_{t}
$$

The value of the portfolio $P_{t}$ changes as time passes because of changes in $F\left(B_{t}, t\right)$ and $B_{t}$ :

$$
d P_{t}=\theta_{1} d F_{t}+\theta_{2} d B_{t}
$$

Replacing the expressions for $d B_{t}$ and $d F_{t}$ from (27) and (35) in equation (10') yields:

$$
d P_{t}=\left[\theta_{1}\left(F_{1} \alpha B_{t}+F_{2}+\frac{1}{2} F_{11} \sigma^{2} B_{t}^{2}\right)+\theta_{2} \alpha B_{t}\right] d t+\left[\theta_{1} F_{1}+\theta_{2}\right] \sigma B_{t} d W_{t}
$$

If we set $\theta_{1}=1$ units of the puttable bond and $\theta_{2}=-F_{1}$ units of the underlying discount bond, then we eliminate all the randomness in the portfolio:

$$
d P_{t}=\left[F_{2}+\frac{1}{2} F_{11} \sigma^{2} B_{t}^{2}\right] d t
$$

To avoid arbitrage, the portfolio should yield the same rate of return as other risk-free assets:

$$
d P_{t}=r_{t}\left(F_{t}-F_{1} B_{t}\right) d t
$$

and:

$$
F_{2}+\frac{1}{2} F_{11} \sigma^{2} B_{t}^{2}=r_{t}\left(F_{t}-F_{1} B_{t}\right) .
$$

Rearranging terms in (39) yields:

$$
F_{2}-r_{t} F_{t}+r_{t} B_{t} F_{1}+\frac{1}{2} \sigma^{2} B_{t}^{2} F_{11}=0 .
$$


This equation is the Black-Sholes-Merton differential equation. The function $F_{t}=F\left(B_{t}, t\right)$ is found by solving equation (40) subject to the following boundary conditions:

$$
\begin{aligned}
& F_{t} / B_{t} \leq 1 \quad \text { as } \quad B_{t} \rightarrow \infty, \\
& F(0, t)=0, \\
& F\left(B_{T}, T\right)=\max \left(0, E-B_{T}\right) .
\end{aligned}
$$

\section{Puttable bonds written on coupon bonds}

When the underlying bond pays the coupon $C_{B}$, the drift component of the stochastic differential equation needs to be adjusted according to:

$$
d B_{t}=\left(\alpha B_{t}-C_{B}\right) d t+\sigma B_{t} d W_{t}
$$

Hence, the drift of the stochastic differential equation for the puttable bond will also contain the coupon payments:

$$
d F_{t}=\left[F_{1}\left(\alpha B_{t}-C_{B}\right)+F_{2}+\frac{1}{2} F_{11} \sigma^{2} B_{t}^{2}\right] d t+F_{1} \sigma B_{t} d W_{t} .
$$

The corresponding partial differential equation for the puttable bond with coupon $C_{F}$ is:

$$
F_{2}-r_{t} B_{t}+\left(r_{t} B_{t}-C_{B}\right) F_{1}+C_{F}+\frac{1}{2} \sigma^{2} B_{t}^{2} F_{11}=0
$$

and is subject to the same boundary conditions as in (41).

\section{Puttable bonds written on bonds subject to credit risk}

If the intensity or hazard rate $h_{t}$ and the loss process $L_{t}$ are exogenous, the stochastic differential equation for the defaultable indexed bond is:

$$
d B_{t}=\left(r_{t}+h_{t} L_{t}\right) B_{t} d t+\sigma B_{t} d W_{t}
$$

The corresponding partial differential equation is:

$$
F_{2}-\left(r_{t}+h_{t} L_{t}\right) F_{t}+\left(r_{t}+h_{t} L_{t}\right) B_{t} F_{1}+\frac{1}{2} \sigma^{2} B_{t}^{2} F_{11}=0,
$$

subject to the same boundary conditions as in (41). 


\section{REFERENCES}

Ananthanarayanan, A. L., and Eduardo S. Schwartz, 1980, "Retractable and Extendible Bonds: The Canadian Experience," Journal of Finance, Vol. 35, No. 1, pp. 31-47.

Athanassakos, George, 1996, "On the Application of the Black and Scholes Formula to Valuing Bonds with Embedded Options: The Case of Extendible Bonds," Applied Financial Economics, Vol. 6, No. 1, pp. 37-48.

Bliss, Robert R., and Ehud I. Ronn, 1995, "To Call or Not to Call? Optimal Call Policies for Callable U.S. Treasury Bonds," Federal Reserve Bank of Atlanta Economic Review, November-December, pp. 1-14.

Board of Governors of the Federal Reserve System, 1998, Trading and Capital-Markets Activities Manual (Washington: Federal Reserve System).

Branion, Andrew, 1995, "The Government of Canada Bond Market since 1980," Bank of Canada Review, Autumn, pp. 3-21.

Buetow Jr., Gerald W., Frank J. Fabozzi, and Bernd Hanke, 2001, "Impact of Different Interest Rate Models on Bond Value Measures," Journal of Fixed Income, Vol. 11, No. 3, pp. 41-53.

Central Bank of Brazil, 1998, Annual Report 1997, Vol. 34 (Brasília: Central Bank of Brazil).

, 1999, Resolução 2675 (Brasília: Central Bank of Brazil).

, 2001, Annual Report 2000, Vol. 36 (Brasília: Central Bank of Brazil).

,2002a, Annual Report 2001, Vol. 37 (Brasília: Central Bank of Brazil).

,2002b, Circular 3139 (Brasília: Central Bank of Brazil).

, 2002c, Financial Stability Report, Vol. 1, No. 1 (Brasília: Central Bank of Brazil).

,2002d, Política Monetária - Relatório de Atividades 1999 a 2002 (Brasília: Central Bank of Brazil).

,2002e, Resolução 3006 (Brasília: Central Bank of Brazil). 
Crabbe, Leland E., and Panos Nikoulis, 1997, "The Puttable Bond Market: Structure, Historical Experience, and Strategies," Journal of Fixed Income, Vol. 7, No. 3, pp. 47-60.

David, Alexander, 2001, "Pricing the Strategic Value of Puttable Securities in Liquidity Crises," Journal of Financial Economics, Vol. 59, No. 1, pp. 63-99.

De Broeck, Mark, Dominique Guillaume, and Emmanuel Van der Stichele, 1998, "Structural Reforms in Government Bond Markets," IMF Working Paper No. 98/108 (Washington: International Monetary Fund).

Duffie, Darrell, Lasse Heje Pedersen, and Kenneth Singleton, 2003, "Modeling Sovereign Yield Spreads: A Case Study of Russian Debt," Journal of Finance, Vol. 28, No. 1, pp. 119-59.

Duffie, Darrell, and Kenneth Singleton, 1999, "Modeling Term Structures of Defaultable Bonds," Review of Financial Studies, Vol. 12, No. 4, pp. 687-720.

Fabozzi, Frank J., ed., 2001, The Handbook of Fixed Income Securities (New York: McGraw-Hill, $6^{\text {th }}$ edition).

Favero, Carlo A. and Francesco Giavazzi, 2002, "Why Are Brazil's Interest Rates so High?” (unpublished; Milan: University of Milan).

Financial Stability Forum (2000), Report of the Working Group on Capital Flows (Basel: Bank of International Settlements).

Hull, John C., 2000, Options, Futures, and Other Derivatives (Upper Saddle River: Prentice Hall, $4^{\text {th }}$ edition).

International Bank for Reconstruction and Development, and International Monetary Fund, 2001, Developing Government Bond Markets: A Handbook (Washington:

International Bank for Reconstruction and Development and International Monetary Fund).

International Monetary Fund, 2002, Global Financial Stability Report, March 2002: A Quarterly Report by the International Capital Markets Department on Market Developments and Issues, World Economic and Financial Surveys (Washington: International Monetary Fund).

International Organization of Securities Commissions (IOSCO), 1999, Collective Investment Schemes Unit Pricing (London: International Organization of Securities Commissions). 
, 2002, The Development of Corporate Bond Markets in Emerging Market Countries (London: International Organization of Securities Commissions).

Kalotay, Andrew J., and Leslie A. Abreo, 1999, "Puttable/Callable/Reset Bonds: Intermarket Arbitrage with Unpleasant Side Effects," Journal of Derivatives, Vol. 6, No. 4, pp. 88-93.

McLean, Stuart K., ed., 1993, The European Bond Markets: An Overview and Analysis for Money Managers and Traders (Cambridge: Probus Publishing Company, 5th edition).

Merton, Robert C., 1990, Continuous-time Finance (Cambridge: Blackwell Publishers). , 1995, "Financial Innovation and the Management and Regulation of Financial Institutions," Journal of Banking and Finance, Vol. 19, No. 3-4, pp. 461-81.

Missale, Alessandro, 1999, Public Debt Management (Oxford: Oxford University Press).

National Treasury of Brazil (2001), Public Debt: Annual Borrowing Plan 2001, No. 1 (Brasília: National Treasury of Brazil).

, (2002), Public Debt: Annual Borrowing Plan 2002, No. 2 (Brasília: National Treasury of Brazil).

Neftci, Salih N., 2000a, An Introduction to the Mathematics of Financial Derivatives (New York: Academic Press, $2^{\text {nd }}$ edition).

, 2000b, "Domestic Currency Emerging Market Bonds Pricing and Risk Management Aspects," Revista de Análisis Económico, Vol. 15, No. 1, pp. 47-59.

Rebonato, Riccardo, 1998, Interest-Rate Option Models (New York: John Wiley \& Sons, $2^{\text {nd }}$ edition).

Securities and Exchange Commission of Brazil, 2002, Instrução No. 375 (Brasília: Securities and Exchange Commission).

Tufano, Peter, 1996, "Who Manages Risk? An Empirical Examination of Risk Management Practices in the Gold Mining Industry," Journal of Finance, Vol. 51 (September), pp. 1097-1137.

Urich, Thomas J., 1991, “U.K., German and Japanese Government Bond Markets," Monograph Series in Finance and Economics (New York: New York University, Salomon Center). 